\title{
Research on Enterprise Performance Indexes
}

\author{
SUN Bo \\ School of Economics and Management, Jiaying College, Meizhou, P.R. China \\ E-mail: bobxox@126.com
}

Keywords: Enterprise performance; indexes; financial factor; empirical research

\begin{abstract}
Enterprise performance indexes are receiving scholars' attentions. Disputes about them are also numerous. This article reorganized over 90 enterprise performance indexes and refined 10 which are production operation, human management, market reaction, labor market, cost lead, product difference, service difference, management reform, financial performance, humane atmosphere. Subsequently, this paper compressed these ten indexes through empirical research using SPSS. The conclusion is that financial factor is an important segmentation standard.
\end{abstract}

\section{Introduction}

In present era, economic globalization and knowledge economization dominate. Enterprise cannot just rely upon rich material capital, inexpensive labor force and plenary monetary fund of its own to make it larger \& stronger. Instead, enterprise should concentrate its attention on its innovative ability. Regardless of from product, service, flow, or management, innovation will win unique competitive advantage for enterprise. This is also the sure choice of organizations for the present and the future.

\section{About Enterprise Performance}

\section{Explanation of enterprise performance}

Performance in English means 'result or one's act'. If connected with enterprise, it may be understood as 'result of enterprise or its act', i.e. 'enterprise's act in its various aspects'. In Drucker's works, there're many discussions on performance and achievement. In his opinion, 'management does not lie in knowledge, but lies in act. It does not lie in logic, but lies in validation. The only authority of management is its achievement.' [1] From organizational management point of view, performance is the result enterprise expects. It is the enterprise's effective output on different aspects to approach its goal. It should include two sides which are individual and organizational one. The MBA think-tank-pedia's explanation of enterprise performance is: 'enterprise performance refers to enterprise effectiveness of operation and the operator's achievement during certain period. The enterprise effectiveness of operation is mainly displayed in aspects of enterprise's profitability, property operation level, credit capacity, continuous development competence and so on. The operator's achievement is mainly displayed by his production and contribution on aspects of administration, growth \& development in managing \& operating enterprise.' [2] Although this research holds different viewpoint on performance indexes, it still agrees with the above explanation of performance. Therefore, this paper adopts this definition.

\section{Theory of enterprise performance}

Thought of performance management originated from the quality improvement circulating round proposed by Shewhart of Bell Lab in the 1930s, as is well known as P-D-C-A. In process of performance management, it is to establish strategic target, to implement the target, to compare the result with the target (i.e. performance appraisal) as well as to analyze the result to improve performance [3]. Among them, the performance appraisal or the performance evaluation is the difficulty.

American scholar Robert D. Buzzell and his colleagues related enterprise strategy and its performance, using method of PIMS (Profit Impact of Market Strategic) to study problems of corporate performance [4]. Robert G. Ecles thought that combination of product quality, consumer 
satisfaction, market share and innovation capacity and other indexes reflecting enterprise's financial circumstance and its prospects of development could evaluate corporate performance [5]. British scholar Rogers thought that corporate performance management is an integrated yearly management cycle including formulating financial policy, resources goal and policy, setting detailed performance plan, budget, goal, indexes and standard; regular inspection on all these results. Another British scholar Bredrup thought that corporate performance management should be three main mutual connected processes - planning, improving and inspecting [6].

Although scholars have given different definitions to enterprise performance management from different angles, there're several key points which are consistent with each other. First, scholars all thought that performance management is a systematic process. Second, performance management always starts from establishing enterprise's goal and plan. Third, enterprise's performance needs to be weighted or appraised. Fourth, the result obtained through appraisal should be instruction of enterprise performance improvement [7]. All these give this research the operational thought to grasp and measure enterprise performance. Viewpoints of Ecles et al. further extends this kind of thought.

\section{Enterprise performance indexes}

This research combed related literatures surveying enterprise performance. The author discovered that there're numerous \& complicated performance indexes. They are over 90 performance indexes which include sales rate of increment, cash profit margin, new product rate of development, new customer rate of development, enterprise popularity, brand reputation, success rate of pollution discharge, average leaves, average days of every leave, procurement cost, selling costs, wage reform, staff's school record promotion, employees' satisfaction, staff complaints and so on. The author reorganized and reduced them to ten items which are production operation, human management, market reaction, labor market, cost lead, product difference, service difference, management reform, financial performance, humane atmosphere to carry on the surveying (seen in Tab-1). Because the indexes are many, this research plans to compress these performance indexes repeatedly measured to extract main variables through factor analysis.

Table 1 Refining of performance indexes

\begin{tabular}{|l|l|l|}
\hline \multicolumn{1}{|c|}{ Primitive indexes } & $\begin{array}{c}\text { Refined } \\
\text { index }\end{array}$ & $\begin{array}{l}\text { Number } \\
\text { refined }\end{array}$ \\
\hline $\begin{array}{l}\text { serious accident rate, security productivity, secret divulging rate, success } \\
\text { rate of pollution discharge, condition of environmental protection, } \\
\text { informationization construction }\end{array}$ & $\begin{array}{l}\text { production } \\
\text { operation }\end{array}$ & 6 \\
\hline $\begin{array}{l}\text { attendance rate, absence rate, late arriving rate, early leaving rate, average } \\
\text { leaves, average days of every leave, team numbers, training expense, } \\
\text { settlement expense, disbanding expense, staff's school record, staff } \\
\text { professional title, holding rate of special certificate, staff school record } \\
\text { promotion, staff professional title promotion }\end{array}$ & management & 15 \\
$\begin{array}{l}\text { customer satisfaction, customer complaints and ratio, response time limit of } \\
\text { complaints, solution time limit of complaints, rate of on-time delivery, rate } \\
\text { of goods returning, contract delivery rate, rate of suit winning, rate of suit } \\
\text { losing, rate of reconciliation }\end{array}$ & reaction \\
\hline $\begin{array}{l}\text { number of applicants, hire rate of applicants, elimination rate of applicants, } \\
\text { pass rate of preliminary test, pass rate of the second test, consultation } \\
\text { number of applicants, number of want ads, original channel of new staff } \\
\text { (inside or outside) }\end{array}$ & labor market & 8 \\
\hline $\begin{array}{l}\text { ratio of material energy consumption, product cost, procurement cost, } \\
\text { selling cost, labor cost, raw material cost, transportation cost, packing cost, } \\
\text { other costs }\end{array}$ & cost lead & 9 \\
\hline $\begin{array}{l}\text { ratio of technical investment, ratio of research and development expense, } \\
\text { product }\end{array}$ & 7 \\
\hline
\end{tabular}




\begin{tabular}{|c|c|c|}
\hline $\begin{array}{l}\text { new product sales rate, rate of new product development, brand reputation, } \\
\text { brand popularity, number of patents }\end{array}$ & $d \mathrm{~d}$ & \\
\hline $\begin{array}{l}\text { development rate of new customer, market demand grasping, enterprise } \\
\text { reputation, enterprise popularity }\end{array}$ & $\begin{array}{l}\text { service } \\
\text { difference }\end{array}$ & 4 \\
\hline $\begin{array}{l}\text { wage reform, department reorganization, reform of organizational structure, } \\
\text { utilization of outsourcing, training innovation }\end{array}$ & $\begin{array}{l}\text { management } \\
\text { reform }\end{array}$ & 5 \\
\hline $\begin{array}{l}\text { business gross income, trading profit, gross profit, net profit, cash profit } \\
\text { margin, basic income per share, net assets returning ratio, cycling rate of } \\
\text { goods in stock, accumulation rate of capital, increment rate of sales, rate of } \\
\text { capital value-keep or -added, sales profit margin, rate of selling profits } \\
\text { increment, rate of total assets increment, ratio of property to debt, multiple of } \\
\text { attained interest, quick ratio, ratio of cash to flow debt, rate of debt with } \\
\text { interest, rate of probable debt, cycling rate of account receivable, rate of bad } \\
\text { assets, cycling rate of current assets, returning rate of property cash, } \\
\text { safeguard multiple of earnings cash, ratio of cost expense to profit margin }\end{array}$ & & 26 \\
\hline $\begin{array}{l}\text { employee satisfaction, staff complaints, monthly record of conflicts, interest } \\
\text { club }\end{array}$ & $\begin{array}{l}\text { humane } \\
\text { atmosphere }\end{array}$ & 4 \\
\hline
\end{tabular}

(Source: SUN Bo, 2013)

Some performance indexes like cost, management, human affairs and so on are often regarded as enterprise's business secret so they are seldom publicized, as brings certain difficulty to the research's data gathering. Therefore, the research plans to treat them as fuzzy variables. That is to ask the testee to make fuzzy appraisal on enterprise's such aspects as product market, labor market product cost, human resource management and so on, not going into its serious objective absolute value. To some extent, such doing accords with management's attribute of soft science: It's established on foundation of interactive practice between superintendents and supervisees. Why not to opine by staff's appraisal?

\section{Research technique}

To study enterprise performance indexes, this research obtained the data through questionnaire, and carried on statistical analysis to the data using the SPSS statistical analysis software, with factor analysis mainly adopted to realize extraction of performance indexes. This research used questionnaire (paper \& E-mail) aided by interviewing (telephone interview \& personal interview) to get the data. The questionnaire designed used Likert scale, the performance indexes were measured by 5 point rating scale. Before formal questionnaire survey, this research carried on the pre-investigation first, then adjusted some items according to the pre-investigation result. Finally, the formal inquiry was executed on a wide range.

\section{Pre-investigation}

The author first trained some investigators via university's academic teams, and organized a pre-investigation in Meizhou (sample size is 82), as is accorded to test the questionnaire items' reliability and validity. The questions, their order and ways of expression were revised accordingly. The author taught five undergraduate classes in Jiaying College. The samples were collected in these classes via random overall sampling method. Because the senior students were to graduate, most of them had gone on duty for probation. They knew enterprise situation to some extent, and they're aware of this investigation's significance. Therefore, the questionnaire returning-ratio was extremely high which is $100 \%$, as means the 82 questionnaires released were all returned and there weren't any unqualified ones. It could be said that data of this pre-investigation included both educational and practical fields' attitude and view.

\section{Formal investigation}

In the formal investigation, the author mainly adopted methods of convenience sampling and snowball sampling to send out questionnaires. In order to serve the research purpose, the author 
organized the investigators to draw out sample units according to factors like area, profession, scale and so on, then to make contact with the person in charge to confirm that the investigation is acceptable; after that, the questionnaires with detailed filling instruction enclosed were mailed or delivered. There're altogether 300 questionnaires sent out to various kinds of enterprises. The objects investigated were mostly in Guangdong. In order to guarantee representative nature of the sample materials, this research organized investigators (mostly are undergraduate or above) to choose employees according to sex, work department, school record, level, number of working year and so on. Besides paper investigation, the author also sent out questionnaires with filling instruction to schoolmates and friends in enterprises through E-mail, asking them to help in filling. This research altogether sent out 300 questionnaires (150paper questionnaires, 150 E-mail questionnaires), 242 (124 paper ones, 118 E-mail ones) were returned, the questionnaire returning-ratio was $80.67 \%$. As 34 ones were deleted for seriously incomplete or careless filling, the effective questionnaires were 208 , the effectiveness is $85.95 \%$, as reached statistical requirements.

\section{Reliability and validity analyses}

\section{Reliability analysis}

This research firstly examined the reliability. Tab-2 lists that the performance indexes' cronbach's Alpha coefficient is 0.812 , which is bigger than the acceptable level 0.60 suggested by Robert $\mathrm{F}$ Devellis [8]. From this we could know that the questionnaire items' consistency, dependability, reproducibility and stability were all ideal, as demonstrates good internal reliability.

Table 2 Coefficient of reliability

\section{Validity analysis}

\begin{tabular}{|l|l|}
\hline Cronbach's $\alpha$ & Items \\
\hline .812 & 10 \\
\hline
\end{tabular}

The author obtained the result of performance indexes' sampling adequacy through exploratory factor analysis, as seen in Tab-3.

Table 3 Performance indexes' sampling sufficiency

\begin{tabular}{|l|l|l|}
\hline $\begin{array}{l}\text { Kaiser-Meyer-Olkin Measure } \\
\text { Adequacy. }\end{array}$ & of Sampling & .897 \\
\hline Bartlett's Test of Sphericity & $\begin{array}{l}\text { Approx. } \\
\text { Chi-Square }\end{array}$ & $\begin{array}{l}1433.6 \\
88\end{array}$ \\
\hline & df & 45 \\
\hline & Sig. & .000 \\
\hline
\end{tabular}

From Tab-3 we can see that performance indexes' sampling adequacy's KMO value is 0.897 , as shows that the partial correlation between indexes is big, the sample size is sufficient. And the Bartlett's test of sphericity also passes high significance examination of $1 \%$, as shows that factor model is appropriate and the questionnaire's structural validity is high.

\section{Extraction of performance indexes}

According to result of validity analysis, the performance indexes are suitable to make factor analysis. Therefore, the author considers reducing the indexes' dimension to extract fewer representative indexes. The total variance explained table is as follows.

Table 4 Total Variance Explained: extraction of performance indexes

\begin{tabular}{|c|c|c|c|c|c|c|c|c|c|}
\hline \multirow[t]{2}{*}{$\begin{array}{l}\text { Comp } \\
\text { onent }\end{array}$} & \multicolumn{3}{|c|}{ Initial Eigenvalues } & \multicolumn{3}{|c|}{$\begin{array}{l}\text { Extraction Sums of Squared } \\
\text { Loadings }\end{array}$} & \multicolumn{3}{|c|}{$\begin{array}{lr}\text { Rotation Sums } & \text { of } \\
\text { Squared Loadings } & \\
\end{array}$} \\
\hline & Total & $\begin{array}{l}\% \text { of } \\
\text { Varianc } \\
\mathrm{e}\end{array}$ & $\begin{array}{l}\text { Cumulati } \\
\text { ve } \%\end{array}$ & Total & $\begin{array}{l}\% \text { of } \\
\text { Variance }\end{array}$ & $\begin{array}{l}\text { Cumulati } \\
\text { ve } \%\end{array}$ & Total & $\begin{array}{l}\% \text { of } \\
\text { Varia } \\
\text { nce }\end{array}$ & $\begin{array}{l}\text { Cumul } \\
\text { ative } \%\end{array}$ \\
\hline 1 & 5.692 & 56.920 & 56.920 & 5.692 & 56.920 & 56.920 & 5.413 & 54.13 & 54.131 \\
\hline
\end{tabular}




\begin{tabular}{|l|l|l|l|l|l|l|l|l|l|}
\hline & & & & & & & & 1 & \\
\hline 2 & 1.643 & 16.430 & 73.351 & 1.643 & 16.430 & 73.351 & 1.922 & $\begin{array}{l}19.22 \\
0\end{array}$ & 73.351 \\
\hline 3 & .498 & 4.975 & 78.326 & & & & & & \\
\hline 4 & .490 & 4.899 & 83.225 & & & & & & \\
\hline 5 & .395 & 3.946 & 87.172 & & & & & & \\
\hline 6 & .360 & 3.604 & 90.775 & & & & & & \\
\hline 7 & .282 & 2.817 & 93.592 & & & & & & \\
\hline 8 & .251 & 2.514 & 96.106 & & & & & & \\
\hline 9 & .223 & 2.232 & 98.337 & & & & & & \\
\hline 10 & .166 & 1.663 & 100.00 & & & & & & \\
\hline
\end{tabular}

Tab- 4 shows that 10 primitive performance indexes could be compressed to 2 indexes that could explain $73.351 \%$ of the total variance. The load matrix of these indexes is in Tab-5 as follows.

Table 5 Component Matrix: extraction of performance indexes

\begin{tabular}{|l|l|l|}
\hline \multirow{2}{*}{} & \multicolumn{2}{|l|}{ Component } \\
\cline { 2 - 3 } & 1 & 2 \\
\hline production operation & .846 & -.081 \\
\hline human management & .829 & -.003 \\
\hline market reaction & .781 & .060 \\
\hline labor market & .833 & .215 \\
\hline cost lead & -.502 & .804 \\
\hline product difference & .800 & .153 \\
\hline service difference & .810 & .149 \\
\hline management reform & .797 & .158 \\
\hline financial performance & -.236 & .925 \\
\hline humane atmosphere & .863 & .114 \\
\hline
\end{tabular}

The load matrix could be orthogonally rotated. The obtained rotated factor load matrix is in Tab-6.

Table 6 Rotated Component Matrix: extraction of performance indexes

\begin{tabular}{|l|l|l|}
\hline & \multicolumn{2}{|l|}{ Factor } \\
\cline { 2 - 3 } & Non-financial act & Financial act \\
\hline production operation & .795 & -.301 \\
\hline human management & .799 & -.220 \\
\hline market reaction & .770 & -.147 \\
\hline labor market & .860 & -.011 \\
\hline cost lead & -.274 & .908 \\
\hline product difference & .812 & -.063 \\
\hline service difference & .821 & -.069 \\
\hline management reform & .810 & -.057 \\
\hline financial performance & .015 & .955 \\
\hline humane atmosphere & .863 & -.116 \\
\hline
\end{tabular}

Observation suggests that the rotated factor load matrix is more explanatory. Common factor 1 weighs much on indexes except 'cost lead' and 'financial performance' while common factor 2 
weighs much in the two very indexes. Therefore, both common factors may be respectively renamed as 'non-financial act' and 'financial act'.

\section{Summary}

The academic field's opinions on enterprise performance indexes are diverse. This research reorganized over 90 performance indexes and refined them to ten items. Then these ten enterprise performance indexes were compressed by factor analysis to seek representative performance indexes. 'Non-financial act' and 'financial act' are the representative factors obtained, as suggests that financial factor might be the dividing line of performance indexes. And in practice it might be the important segmentation principle to design or choose specific enterprise performance indexes.

Moreover, in the primitive correlation matrix, this research discovered that 'financial performance' is irrelative with 'humane atmosphere' since the correlation coefficient is only - 0.117. This is contradicted with people's traditional standpoint that 'if an enterprise's financial condition is fine, its organizational morale must be high'. Then, how should we explain this? This research believes that in era of knowledge economy, the knowledge staff cares more about top level pursuits which are self-realization, self-respect, else-respect and so on. Perhaps this dominates staff's mood, thus causes financial performance irrelative with humane atmosphere. In practice, phenomena of some enterprises in 'aristocrat period' whose financial statement are satisfactory while their morale is low are common cases. Maybe this problem could be explained from it.

\section{References}

[1] Peter F Drucker, and Wang Xiliu, "Management field in change" Shanghai: Shanghai Translation Publishing House, 1999. p. 29-31, (in Chinese).

[2] Unkonwn, "Enterprise performance", http://wiki.mbalib.com/wiki/\%E4\%BC\%81\%E4\%B8\%9A\%E7\%BB\%8F\%E8\%90\%A5\%E7\%BB \%A9\%E6\%95\%88, 2009-11-09. (in Chinese)..

[3] Li Yanping, Yu Zezhong and Li Xiyuan, "Human resource management," Wuhan: Wuhan University Publishing house, 2002, p.243-244. (in Chinese).

[4] Robert D. Buzzell, etc. and Wu Guanzhi, "Strategy and performance - - PIMS principle," Beijing: Huaxia publishing house, 2000, p.19-31. (in Chinese).

[5] Peter F Drucker, etc., "corporate performance evaluation," Beijing: China Renmin University Publishing house, 1999, p. 23-41. (in Chinese).

[6] Bredrup "Performance measurement in a changing competitive industrial environment: Breaking the financial paradigm," University Trondheim (Norway), 1995.

[7] Li Yanping, Yu Zezhong and Li Xiyuan, "Human resource management," Wuhan: Wuhan University Publishing house, 2002, p. 244. (in Chinese).

[8] Robert F.Devellis. "Scale Development: Theory and Applications," Applied Psychological Measurement, vol. 15(4) , p. 425-426. 1991. 